\title{
The Selection of Partners in Technological Alliances Projects
}

\author{
Marcos Paixão Garcez', Roberto Sbragia ${ }^{2}$
}

\begin{abstract}
The study seeks to understand the factors for selecting partners in technology alliances prevailing in the Brazilian chemical industry. The data comes from two successive stages. Based on the theory of resource-based view (RBV), together with qualitative evidences from a previous study carried out in the Brazilian petrochemical leader (analyzing 20 technological alliances with different kind of partners, and encompassing diverse types of projects - incremental, platforms, radical and basic science), it was possible to identify domains in the exploitation-exploration continuum and generate the conceptual model and the derived research hypotheses to be tested in the quantitative research, using a websurvey for data collection in the Brazilian chemical industry. By using the techniques of Multinomial Logistic Regression and Binomial Logistic Regression, the study outlines a series of relationships determining the most important selection factors depending on the type of partner and type of project. Finally, implications are discussed.
\end{abstract}

Keywords: strategic alliances; technology alliances; partnerships; cooperation; project management.

'University Nove de Julho (UNINOVE). E-mail: mpgarcez@uninove.br

${ }^{2}$ University of São Paulo (USP). E-mail: rsbragia@usp.br

ISSN: 07 I8-2724. (http://www.jotmi.org)

Journal of Technology Management \& Innovation (c) Universidad Alberto Hurtado, Facultad de Economía y Negocios. 


\section{Introduction}

Due to increased competition and the consequent need to have shorter deadlines to launch projects of products and services in one continuous flow, while worrying about also introducing radical innovations in the long term, technological alliances have occupied increasing space in the agenda of business growth. They provide risk mitigation in projects of greater uncertainty due to sharing of financial and project risks and by accessing the expertise of partners.

Knowledge expands at a high speed and processes become more complex, making it difficult for one organization to possess, alone, the necessary competences to survive. The technological alliances have been widely used in development projects, and seem to bring the reduction of investment and return deadlines, by sharing resources, competences and risks between the partners. The $X X I$ century is called by some scholars of the subject, such as Austin (2000), the era of alliances. The business environment already has indelibly, a complex relational architecture, both formal and informal, which cannot exist without the presence of alliances, many of them with strategic connotation, which provide competitive advantages to partners.

Although strategic alliances have existed for some time, it was in the 90s that was perceived a rapid acceleration of this type of cooperation agreement, its scope and its coexistence with other organizational relationships. Therefore, it is this very moment that broadens academic research on the topic, motivated by the growing interest for its novelty business and as a social phenomenon to be investigated. The cooperation is imperative to industrial enterprises in the new competitive environment, permeated by continuous innovation, globalization, increased competition, openness and saturation of markets, dilution risks and expiration of patents. More than two decades ago, Twiss (1986) already noted this trend, identifying that although external cooperation in $R \& D$ received relative share of investments in smaller scale than other strategies, the annual growth rates would grow significantly, as evidenced by data from countries like France and the UK.

The intensification of the competitive environment, derived from the globalization process, catalyzes the adoption of this practice of forming alliances on a level never seen before, as companies are being pressed by the need to develop new skills and competences. To that end, they should make use of new resources to introduce new products, processes and business models, and often in new markets, in very shortterm periods if compared with the past.

Thus, currently, strategic alliances are seen as a very logical way to access and develop new markets, be they geo- graphical or business ones, to acquire new knowledge and technologies and to obtain economies of scale, as well as to the development of new products. Nowadays it is almost an established consensus that it is virtually impossible for a company to maintain its competitive advantage without the adoption of external cooperation activities (Jonash and Sommerlatte, 200I). The new paradigm reconciles and catalyzes existing internal and external efforts for innovation, as suggested by the model of Open Innovation, which emphasizes the systematic collaboration between the parties involved (Chesbrough, 2003).

However, although contradictory this may seem, the theory about the process of establishing strategic alliances can still be considered nascent, with only a few theoretical models, despite the extensive literature on: (i) the framework of alliances in the various economic theories, (ii) the process of selection and implementation - with their different stages of consolidation, (iii) the specific factors related to the selection of partners according to the task (task related) and to the partner (partner related); and (iv) the determinants of performance in alliances. Nevertheless, studies concerning the selection of partners relate mainly the choice of partner to the organizational characteristics of this partner, as its technology strategy, its industry, its size, its degree of internationalization and their complementarity with the partner - i.e. only at the macro level (firm level), not engaging in further analysis includind the micro-level projects (project level). Dacin, Hitt and Levitas (1997) said that even though partner choice being a central point on the performance of alliances, little research has devoted explicit attention to this issue (Dacin, Hitt and Levitas, 1997, p.4).

So, the selection of a partner can be considered the most important activity in the formation of the alliance (Dacin, Hitt and Levitas, 1997; Elmuti and Kathawala, 200 I; Sorensen and Hort, 1998), but is generally underestimated (Koza and Levin, 2000; Medcof, 1997). Despite some strong empirical evidence, the managers only recently began to devote greater attention to this crucial strategic decision (Ariño et al., 1997). Forcefully, selecting the right partner is crucial in the process of selection (Dacin, Hitt and Levitas, 1997; Devlin and Bleackley, 1988).

Given the relative incipiency of the subject in academic research - around 25 years, the nature and scope of the studies in quantities far from being saturated, besides sometimes contrasting results, we derive from the literature review that there are no knowledge that are strongly consolidated in the identification of conditions for the establishment of alliances, assisting in the detection of selection factors of alternative technology alliances and partners and defining the most appropriate in advance, especially taking into account not only the agents themselves - the partners, but empha-

ISSN: 0718-2724. (http://www.jotmi.org)

Journal of Technology Management \& Innovation (c) Universidad Alberto Hurtado, Facultad de Economía y Negocios. 
sizing as a relevant unit of analysis the very characteristics of the predominant nature of innovation and the types of innovation projects.

Moreover, we notice the absence of normative studies that relate knowledge, one of the most important resources, with the specific motivations of the alliance in the management of the selection, the project and progress of the alliance, as advised by Grant and Baden-Fuller (2004.) In order to fill this gap, this study aims to investigate the selection process of partners in bilateral technology alliances without equity, in terms of identifying the determinants of partner selection from the standpoint of chemical industrial companies in Brazil.

To meet this goal, we investigate the following questions: -What were the kinds of technological bilateral strategic non-equity alliances and which were the characteristics of the most significant associated projects identified in the sample?

-What were the most relevant conditioning factors for selecting the type of partners in these alliances, regarding the characteristics of projects and prospective partners? How do these conditioning factors in the selection of partners relate to different types of partners in the sample of companies studied?

\section{Theoretical Foundation}

\section{The Resource-Based View}

The resource-based view is chosen as the main guide in the present study, given its prevalence in the literature and in the scope and findings identified in several empirical and theoretical studies (Eisenhardt and Schoonhoven, 1996; Lowe and Taylor, 1998; Fritsch and Lukas, 200I; Tether, 2002; Miotti and Sachwald, 2003; Grant and Baden-Fuller, 2004; Lavie, 2006). In this perspective, firms are seen as having resource bundles (Eisenhardt and Schoonhoven, 1996), which may be competences or assets, tangible (financial assets, patents, technologies, etc.) or intangible (reputation, management competences, etc.) This theory has been widely used in research on alliances (Grant and Baden-Fuller, 2004; Lavie, 2006), mainly by consensus that the cooperative alliances arise when a company in a given situation of unavailability of critical resources, seeks access to these resources through the cooperation with the partner, allowing both to share risks and costs (Staropoli, 1998; Grant and Baden-Fuller, 2004; Lavie, 2006). The competitive advantage results from the resources that companies contribute in the cooperative relationships and also from the complementarity of partners' resources.

\section{Selection factors related to the task and the partner}

In studies that have become classics on the subject of alliances, Geringer (1991) analyzes the relationship between the characteristics of potential partners and the performance of joint ventures, one of the types of corporate entrepreneurship. In these studies, Geringer (1991) discusses the relative importance that companies give to factors related to the tasks and to the partners, and they vary depending on the strategic context, on the alliance, on the culture and nationality (Arinõ et al., 1997; Geringer, 1991).

When we refer to factors related to the tasks, generally partners seek strong complementarity in each other, filling the existing gaps. Geringer (I99I) suggest some factors related to the task: (I) access to patents, (ii) the existence of technical know-how, (iii) availability of financial resources, (iv) managerial experience, and (vi) access to supply chains and new markets. It is also possible to consider a subcategory of factors directly related to the task, more specifically the demands of projects (Geringer, 1991). This concept is important for the present study, which analyzes the formation of alliances by introducing the micro point of view, at the project level, as crucial in the selection of partners. It is possible to classify that the present study is concerned with introducing thus the project-based level.

Thus, with regard to aspects directly related to project characteristics, Nalebuff and Brandenburguer (1996) argue that risk, time and cost are the main driving forces for companies to cooperate. The risk is related to uncertainties, whether they be technological, financial or marketing. The alliance tends to reduce these risks by sharing knowledge, physical resources and experiences. The period of project development (lead-time) is key to successful marketing.Alliances can provide the acceleration of development time by sharing expertise and R\&D tangibles, focusing on different tasks and increased investment. In turn, the cost tends to decrease with cooperation, reducing the overall investment and maximizing the shared synergies obtained in the process.

The second category, referring to the partner-related criteria, concerns those variables that become relevant only if the mode of the chosen strategy involves the presence of multiple partners, analysis that should be preceded by meeting the same criteria identified in the first category (Geringer, 1991). That is to say that only they become more important if the alliance contains more than two partners simultaneously and that they have met the criteria identified in the first dimension. In this case, the companies generally seek similarity in the partner, such as an organizational culture which is not very divergent, the experience in alliances, the convergence of interests of the partners and partner

ISSN: 07 I8-2724. (http://www.jotmi.org)

Journal of Technology Management \& Innovation (c) Universidad Alberto Hurtado, Facultad de Economía y Negocios. 
confidence, treated as criteria to be analyzed related to the partner.

Geringer and Frayne (1993) suggest the following factors related to partners: (I) nationality, (ii) a similar organizational culture, (iii) previous experience in alliances, (iv) convergence of interests the partners (compatibility), and (v) reputation and the ensuing trust. Differentiating the reputation from trust, reputation is defined as the perception of quality over time, influenced by market history. A positive reputation can lead to trust.

\section{Cooperation with different types of partners}

The most common type of cooperation is between suppliers and customers, the so-called vertical alliance (Verspagen and Duysters, 2004), which takes a very important role in research and development, through access to resources such as technology, information on market needs and on markets. Cooperation with suppliers was studied by Sako (1994), Liker et al (1996) and Bidault, Despres and Butler (1998) in Japanese companies, and Tether (2002), in the context of U.S. and European companies performing "downsizing" and focusing on key activities The alliance with suppliers has as its basic premise the complementing of the internal efforts of
R\&D, rather than their replacement. Cooperation with customers, in turn, is especially important in reducing the uncertainties of the market (Kotabe and Swan, 1995; Balachandra and Friar, 1997; Savioz and Sannemann, 1999), through the transference of knowledge on market needs and pricing, on consumer habits, and the consequent increased likelihood of commercial success of products launched (Shaw, 1994). In turn, the vertical alliances with universities and research centers have special appeal when the company requires intensive effort in R\&D, beyond their capabilities and knowledge infrastructure (Arora and Gambardella, 1990;Archibugi and Coco, 2004).

The so-called horizontal cooperation in pursuit of rapid growth and market leadership through access to often similar, and / or complementary resources, is regarded particularly to alliances between competitors in order to increase economies of scale, market concentration, dilution of the financial, technical and commercial risks, by improving the competitive position of the partners. It happens especially in large projects, when the necessary resources and exposure to risks outweigh the capabilities of individual firms and by firms that operate in the same industry and have similar problems, thus increasing the need for access to resources, not always complementary (Tether, 2002; Miotti and Sach-

\begin{tabular}{|l|l|l|}
\hline Independent Variables & $\begin{array}{l}\text { Dependent Variable } \\
\text { Selection factors related to the task : } \\
\text { - Complementarities between partners } \\
\text { (technological and market) } \\
\text { - Financial resources demand of the project } \\
\text { - Risks of the project (financial, technological, } \\
\text { market and competitive) }\end{array}$ & $\begin{array}{l}\text { Nature of the partner } \\
\text { Universities and Research } \\
\text { Institutes } \\
\text { - Duration of the project } \\
\text { Clients } \\
\text { Suppliers }\end{array}$ \\
\hline $\begin{array}{l}\text { Selection factors regarding the partner: } \\
\text { - Previous experience in alliances (2 items) } \\
\text { Trust between partners (4 items) } \\
\text { - Convergence of the expectations between } \\
\text { partners for the continuity of the project. }\end{array}$ \\
- Organizational culture similarity.
\end{tabular}

Figure I: Conceptual model of research.

The variables are divided into two groups, the group with factors related to the task, and the group with factors related to the partner.

ISSN: 07 I8-2724. (http://www.jotmi.org)

Journal of Technology Management \& Innovation (c) Universidad Alberto Hurtado, Facultad de Economía y Negocios. 
wald, 2003). Examples of such an association occur in very high-tech sectors (Miotti and Sachwald, 2003; Garcia and Velasco, 2004), such as pharmaceutical and chemical industries, as well as in large-scale projects. In such alliances, among competing companies, they are joined bringing additional resources or not, but always aiming at the dilution of risks and reduction of costs. A frequent concern in this type of alliance lies in the competitive risk to which companies have to deal with, balancing incentives and risks of cooperative R\&D (Bruno and Vasconcellos, 2003; Powell, Kogut and Smith-Doerr, 1996; Cassiman and Veugelers, 1998) .

\section{Research Methodology}

This study was characterized by two sequential phases, the first qualitative and the second quantitative, each one with specific characteristics and purposes, namely: (I) Phase I, of an exploratory and inductive nature, through one single case study built in order to deepen the constructs, identify variables and their operationalization and generate hypotheses to be tested, and (ii) Phase 2, of a descriptive and deductive nature, through field survey in the Brazilian chemical industry, in order to test the previously generated hypotheses.

\section{Conceptual Model and research variables}

Figure I shows the theoretical-conceptual model for the study, based on the literature review.

\section{Task Related Factors}

Demand for funding of the project: the demand for project resources is assessed. They are not created and linked financial figures at intervals, only the judgment of perception in a five-point interval scale with the extremes very low and very high demand for funds, since a small project for a large company may be equivalent to a large project for a small business, depending on their financial status. The intention is to access the intensity of the financial demand of the project for that company, indirectly guiding to the need for cooperation.

Project duration: there is the period of project development. Intervalar scale varies from very low to very high duration. We decided on this approach, and not actually the time in days of project, since there is strong variance of the average maturity of development in different chemical sub-sectors, ie, a project that can, for a given sub-sector, be considered long-term (eg. four years long), to another, such as pharmaceuticals, can be treated as short term. What is accessed is the relativization of that given project within the concept of the company, not an absolute comparison of the periods in days of projects of all companies, given this characteristic of heterogeneity in the chemical sector.
Project risk, assesses the overall risk of the project, in scale with the extremes of very low to very high risk. It unfolds to the danger of risk items in four projects, which are valued at their proportionality to the overall risk and in scale with the extremes of very low to very high risk, namely: (i) Financial risk: associated to the level of financial exposure of the project; (ii) Market risk: associated with the probability of commercial success of the project; (iii) Technological risk: associated with the probability of technical success of the project and, (iv) Competitive risk: associated with the risk of competitive strengthening of the partner.

The best fit according to Cronbach's alpha was made by merging the first three items of risk in a variable called RISK, which refers to the inherent risks of the project, and remained as the variable part of the competitive risk.

Complementarity of partners (C): the total complementarity is broken down into Technological Complementarity between the partners (TC) and Market Complementarity between the partners (MC). These constructs are formed by the Difference of Technological Familiarity (DTF) and Difference of Marketing Familiarity (DMF), which derive from the difference of the familiarities between the partner and the company.

Since they can result in negative numbers, the TC and the $M C$ are simply the modules of the DTF and DMF, respectively. The difference is a metric variable that can result in the range $0-4$, converted to the range $\mathrm{I}-5$, by the following transformations:

$\mathrm{TC}=$ Technological Complementarity $=[\mathrm{TFp}-\mathrm{TFc}]+\mathrm{I} ; \mathrm{MC}$ $=$ Marketing Complementarity $=[\mathrm{NMp}-\mathrm{NMc}]+\mathrm{I}$; Note: The difference in magnitude; $c=$ company and $p=$ partner. As a matter of scale setting, the difference must be increased by a unit, because ifTFE $=5$ and TFP $=1$, the difference is four, and to maintain the five-point scale, is added I. Similarly, if both the organization and partner have the same familiarity degree, the difference would result zero, and to recover the range I-5 should be increased one unit.

The total Complementarity between partners $=\mathrm{C}=$ square root of (TC2 + MC2). It represents the Euclidean distance calculation of analytic geometry. All variables MC, TC and C are constructs formed from the items observed in the questionnaire: Technological Familiarity (TF) and Market Familiarity (MF). The Technological Familiarity is accessed in two dimensions, the Technology Familiarity of the company (TFc) and Technological Familiarity of the Partner (TFp), as well as the Market Familiarity, the Market Familiarity of the company (MFc) and the Market Familiarity of the Partner (MFp). We adopt the following concepts in the study and in the questionnaire, regarding the Technological and Market Familiarity of the company (and of the partner in brackets): 
Technological Familiarity of the company (or partner): degree to which knowledge regarding the core technology of the project already exists in the company (the partner), and the Market Familiarity of the company (or partner): degree to which the characteristics of markets and marketing standards addressed by the project are close to the markets and ways the company does businesses (or partner) and how it understands them.

\section{Partner Related Factors}

Previous experience in alliances: refers to the historical dependencies (path dependencies) of the resource-based theory. Metric variable accessed in scale, with extremes of very low to very high prior experience in alliances. It is subdivided into two items: (a) Partner previous experience in alliances and (b) Previous experience in alliances with that partner.

Confidence in partner:perception of trust and commitment of the partner. It is accessed in scale, with extremes of high to low prior experience in alliances with a partner. It is subdivided into four parts, namely: (I) Trust in the partner regarding the compliance and confidentiality of agreements, (ii) Trust in the partner in meeting deadlines and flexibility for adjustments, (iii) Trust in the partner regarding the contribution of competences and (iv) Trust in the partner reagrding the possession of management processes for interaction and integration.

Convergence of expectations between the partners fostering growth and continuity of the project: we seek to identify at what level the objectives of the partners are convergent, or if there is any discrepancy level.

Similarity of organizational culture between the partners: with this variable we seek to identify the proximity of the organizational culture between the partners, since a very large divergence can lead to problems from the early stages of the alliance.

We also define three control variables in the study, as follows:

Size: nominal or ordinal variable, depending on the analysis. We adopted as an indicator of the gross size of the company in 2008, divided into three ranges of values, as follows: I = up to $R \$ 10,500,000.00,2=R \$ 10,500,000.00$ to $60,000,000.00$ and $3=$ above $R \$ 60,000,000.00$, corresponding to the small, medium and large sizes.

Nationality of Partner: Nominal variable that measures the source of major capital of the partner, with I= national and $2=$ international.
Project Type: accesses the type of project according to the classification of Clark and Wheelright (1993), and may take on the following situations: (I): Incremental innovation, (2): Innovation in family of products (platform), (3): Radical innovation or (4): project in basic science (research). We defined each of the categories for classification as follows:

- Research Project (basic science): this is the search for new knowledge, not yet configured as innovations, since they do not seek application at first instance.

- Radical Innovations Project: it is usually applied science, revolutionary, with high-impact differentiation and of difficult imitation.

- New family of products or processes (platform): development of new families of products or processes, with significant change as compared to the existing ones.

- Incremental innovations: minor improvements in existing families of products or processes to service niches or customization.

This variable indirectly accesses the technological complexity of the project, and it could be considered that incremental innovation projects have low complexity, innovation projects in family of products have medium complexity, radical innovation projects have medium to high complexity, and finally, the projects of basic science have high complexity. Thus, in the analysis, it is sometimes regarded as nominal, and in some situations that require the checking of the degree of complexity, it is regarded as ordinal.

Summarizing, the variables selected for the quantitative stage derive from the literature review, shown in Table I, which consolidates the main authors and theoretical trends that supported the choices of the variables observed items and scales, such as the evidence of in-depth case studies of phase I, described in Garcez, Sbragia and Kruglianskasl (2010) and Garcez and Sbragia (20II).

\section{Analysis of Results - Specific Models for testing the hypotheses}

Of the 795 companies invited to take part in the websurvey, which lasted two months, 46 companies responded, resulting in a $5.78 \%$ response rate. Since the unit of analysis is the project, not the company, companies were asked to respond on one or two projects in alliances that were more significant from the strategic point of view in the last five years. Response was obtained on 85 projects, with the majority of respondents speaking about two projects. The sample studied consisted mostly of large companies (58.7\%), with revenues exceeding $\$ 60$ million, followed by medium (28.3\%) and smaller (13\%). Most companies make alliances with customers $(65.2 \%)$ and nearly half of them also do it with Universities or Technological Institutes (54.3\%) and suppli-

ISSN: 07 I8-2724. (http://www.jotmi.org) 
ers (45.7\%), and a considerable portion with other partners, which include technological consulting companies (21.7\%), showing a well-balanced distribution between the different partners. Companies diversify their activities in alliances with the different types of partners. In terms of nationality of the partner, $76.5 \%$ of the most significant alliances were made with Brazilian partners, while $23.5 \%$ were those with international partners. We identified the types of alliances with customers, suppliers, universities and technological institutes and consultancies. The modalities of alliances with companies in other industries and competitors were almost inexistent as significant projects of alliances in our sample, reflecting their lower intensity in the global corporate reality, and especially their lack of participation in the Brazilian cooperative alliances. As more relevant, we identified the alliances with Customers (31.8\%) or Technological Institutes and Universities (31.8\%), followed by alliances with Suppliers $(21.2 \%)$ and finally Others (14.1\%) in terms of episodes of alliances projects more significant in the companies mentioned. Regarding the types of projects, the predominant are the platform-type projects that create new families of products or processes, with $50.6 \%$ of alliances, followed by incremental innovations, with $29.4 \%$, by radical innovations, with $12.9 \%$, and finally, the basic science projects, representing $7.1 \%$ of the projects. Together, the projects of the platform type and incremental type are predominant and accounted for $80 \%$ of the sample, and the projects of greater complexity accounted for the remaining $20 \%$, as it was expected based on the literature of portfolio of projects (Clark and Wheelright, 1993).
We used the sofware SPSS v. 17 for statistical analysis. Table 2 presents the tests of hypotheses of the study, derived either from the literature review, or from the results of the qualitative phase. Given its exploratory nature and the absence of detailed researches accessing the specific factors of selection at the project level, the hypotheses derived almost entirely on empirical data of the qualitative phase (Garcez, Sbragia and Kruglianskas, 2010; Garcez and Sbragia, 20II), with other contributions from the literature in some cases. To test the hypotheses, we combined a variety of methodologies, depending on the proposition, and keeping up a hierarchy of decision on the full support (in bold in the table), partial support or rejection of the hypothesis, considering the priority of the logistic regression and performing other tests to confirm. If not supported by logistic regression, we attempted to support by non-parametric hypothesis testing, correlation analysis, correspondence analysis and descriptive statistics. Depending on the situation, we decided for full or partial support of the hypothesis, depending on the significance level obtained. In case of total absence of any support by the statistical techniques used, the hypothesis is rejected. Besides the Multinomial Logistic Regression (MLR), we made use of the Binomial Logistic Regression (BLR) to compare two groups, always using the control variables introduced initially, and later the independent ones, using the forward stepwise method. Nonparametric univariate analyzes are also used to compare means of independent samples (since data normality was not obtained), like the Mann-Whitney test when the variables are at least ordinal, as well as the chisquare, for nominal variables. The Mann-Whitney test does

\begin{tabular}{|l|l|l|l|l|l|}
\hline Category & $\begin{array}{l}\text { Variables } \\
\text { (Direct or } \\
\text { constructs) }\end{array}$ & $\begin{array}{l}\text { Items mea- } \\
\text { sured }\end{array}$ & Conceptual base & $\begin{array}{l}\text { Type } \\
\text { and category }\end{array}$ & Operationalization \\
\hline $\begin{array}{l}\text { Task related } \\
\text { factors }\end{array}$ & 5 & 10 & $\begin{array}{l}\text { Geringer (199I) } \\
\text { Geringer and } \\
\text { Fraine (1993) } \\
\text { Roberts and } \\
\text { Berry (1985) } \\
\text { PMBOK (2004) }\end{array}$ & Independent / metric & Scale I-5 \\
\hline $\begin{array}{l}\text { Partner re- } \\
\text { lated factors }\end{array}$ & 4 & 10 & $\begin{array}{l}\text { Geringer (199I) } \\
\text { Geringer and } \\
\text { Fraine (1993) }\end{array}$ & Independent / metric & Scale I-5 \\
\hline $\begin{array}{l}\text { Project type, } \\
\text { size and } \\
\text { nationality }\end{array}$ & 3 & 3 & $\begin{array}{l}\text { Clark e Wheel- } \\
\text { right (1993) }\end{array}$ & $\begin{array}{l}\text { Control / } \\
\text { nominal categorical }\end{array}$ & $\begin{array}{l}\text { Categorical: 4 (project), } \\
\text { (size) and 2 (nation- } \\
\text { ality) }\end{array}$ \\
\hline $\begin{array}{l}\text { Partner } \\
\text { category }\end{array}$ & 1 & 1 & Various (*) & $\begin{array}{l}\text { Dependent / } \\
\text { categorical }\end{array}$ & 5 categories \\
\hline
\end{tabular}

Table I:Variables, conceptual base and scale. Source:Author

(*)With regard to the type of partner, we carried out a survey of several scholarly works, categorizing the agents, listed below:Tether, 2002;Verspagen and Duysters, 2004; Sako, 1994; Kotabe and Swan, 1995; Balachandra and Friar, 1997; Savioz and Sannemann, 1999; Arora and Gambardella, I990; Archibugi and Coco, 2004; Miotti and Sachwald, 2003; Garcia andVelasco, 2004; Powell, Kogut and Smith-Doerr, 1996; Cassiman and Veugelers, 1998.

ISSN: 07 I8-2724. (http://www.jotmi.org)

Journal of Technology Management \& Innovation (C) Universidad Alberto Hurtado, Facultad de Economía y Negocios. 
not compare the media per se, but the average rankings in positions of the two samples under comparison.

According to the results obtained, concerning the selection factors related to the task and to the partner, alliances with Universities and Technological Institutes have high demand for financial resources, high TC and MC, have low competitive risk, embed high level of overall experience, with low organizational similarity partners, and are mostly made in the projects of high complexity (radical and basic science), of high technological risk, especially with national partners, revealing the difficulty national companies have to foster agreements with international universities. In alliances with customers, the duration and competitive risk is high, while the $M C$ is low, only getting a level higher than in alliances with suppliers. The complexity of projects is low, incremental projects and platforms prevail, and the partners are predominantly national. With suppliers, alliances have low MC and high levels of convergence of expectations and similarities in organizational cultures. This has the highest degree of presence of international partners when compared to other categories of partners. Alliances with consulting firms show low duration and competitive risk (possibly through different areas of activity and size), the TC is low and the MC is high, the previous experience of the partner and with the partner is considered low (as expected, given that these alliances are formed for projects of short duration and specific demands), the similarity of organizational culture is high, the complexity of projects is low, and alliances with such partners have a higher portion of international partners than alliances with Universities, Tls and customers, only being surpassed by alliances with suppliers. The basic science projects, compared to the others, showed the highest levels of financial demand, duration, and TC relative participation of local partners. The radical innovation projects show the highest levels of financial, technological and market risk perceived, possibly explained by the fact that basic science projects are more uncertain even though they do not aim at immediate application, being more focused on the generation of knowledge. The platform projects have the highest levels of MC, justified by the high participation of customers in this category. The incremental innovation projects associate high competitive risk and are conducted mainly with consultants and suppliers, along with significant participation of international partners.

\section{Concluding Remarks}

As previously stated, this paper aimed to emphasize the project level attributes in the partner selection process, by means of two successive empirical researches. First, we based in one in-depht literature review joined with some indutive preliminary evidences picked up from one qualitative study focusing on technological alliances. In that study, twenty alliance-based projects were analyzed and the results pointed to different patterns depending on the nature of the project. It enabled the building of the research design for the quantitative study in the Brazilian chemical sector, in order to check deductively the more prevalent and significant relations.

So, the study, based on extensive review of the literature and on evidence from exploratory in-depth case studies, set out to test a series of generated hypotheses, taking into account the specific demands in the technological projects alliances. Thus, this study focused on the selection of partners from a different angle from previous studies, which emphasize selection variables in the enterprise level, not being very specific about the characteristics of the project. Because we seek to relate characteristics of projects in the selection of partners, the study drew from a high number of hypotheses. Of 25 hypotheses or subhypotheses tested, I was not deemed testable (4\%), 7 did not receive support ( $28 \%), 2$ received partial support (8\%) and 15 received support (60\%). It is hoped that the research has added new evidences to this important field of knowledge, both from the theoretical as well practical point of view. From the theoretical side, we can assume that one more contingencial approach for the partner selection can be both desirable as crucial when analyzing intensive technological sectors showing multitasks process with high complexities involved. For the practioners, we hope this study can shed light in terms of insights for establishing the managerial important factors to be considered when electing one partner, depending on the task. Moreover, the evidences can help to establish one portrait of the Brazilian cooperation situation, enabling also the action related to public policies in order to further emulate one more wide and added-value cooperation among the actors.

As a limitation to the study, it was focused on just one sector, does not allowing generalization of findings to other industries. As suggestions for future studies, a multisectoral quantitative research could be carried out. We also envisage the possibility of advances in qualitative research, in which the views of both the parent company and the selected partner could be analyzed. Studies analyzing the Dynamic Capabilities of both companies in the bilateral alliance, depending on the nature of the project, could also contribute to considerable advances in the subject; as well as studies correlating sectors with different degrees of technological intensity, according to the OECD classification. 


\begin{tabular}{|c|c|c|}
\hline Hypothesis & Statistical prove & Result \\
\hline $\begin{array}{l}\text { HI:The demand for resources required for } \\
\text { the project is more positively related to } \\
\text { alliances with universities / Tls when com- } \\
\text { pared to suppliers, customers and others. }\end{array}$ & $\begin{array}{l}\text { For the MLR, the hypothesis is true when comparing } \\
\text { universities and Tls with suppliers (with significance), } \\
\text { customers (without significance), but not in relation to } \\
\text { consultants, who receive the highest rating of intensity in } \\
\text { this item, perhaps by short-term disbursement. However, } \\
\text { in BLR, the hypothesis is supported.The Mann-Whitney } \\
\text { test, despite the difference in the average ranking of } \\
\text { II.4\% as far as the hypothesys is concerned, there is } \\
\text { no statistical significance (p value of } 0.383 \text { ). Thus, the } \\
\text { hypothesis is only partially supported. }\end{array}$ & $\begin{array}{l}\mathrm{HI} \text { is partially } \\
\text { supported }\end{array}$ \\
\hline $\begin{array}{l}\text { H2:The project duration is more positively } \\
\text { related to alliances with universities / Tls } \\
\text { when compared to alliances with others. }\end{array}$ & $\begin{array}{l}\text { In MLR, we see that when comparing the alliances } \\
\text { with customers in relation to universities and TIs, the } \\
\text { relationship is reversed, i.e., the greater the period } \\
\text { of development, the greater the likelihood that the } \\
\text { alliance is conducted with customers. Likewise, in the } \\
\text { BLR the hypothesis is not supported, neither is it in the } \\
\text { Mann-Whitney test, leading to its rejection. This arises as } \\
\text { an unexpected result, since the projects with universities } \\
\text { and Tls theoretically associate with more radical projects } \\
\text { and basic science, which tend to be longer. Nevertheless, } \\
\text { it reflects the situation found in the Brazilian chemical } \\
\text { scenario in which there is a significant part of alliances } \\
\text { with universities / Tls dealing with incremental innova- } \\
\text { tions. }\end{array}$ & $\mathrm{H} 2$ is not supported \\
\hline $\begin{array}{l}\text { H3a. The financial risk is more positively } \\
\text { related to alliances with competitors when } \\
\text { compared to the others. }\end{array}$ & $\begin{array}{l}\text { This hypothesis could not be tested, since there was only } \\
\text { one case of alliance with competitors. The hypothesis } \\
\text { derived from case studies in company A, which holds } \\
\text { alliances with overseas competitors, with great financial } \\
\text { risk, given the scale of operations. }\end{array}$ & $\mathrm{H} 3 \mathrm{a}$ is not testable \\
\hline $\begin{array}{l}\text { H3.b. The technological risk is more posi- } \\
\text { tively related to alliances with universities } \\
\text { /TIs, compared with customers, suppliers } \\
\text { and others. }\end{array}$ & $\begin{array}{l}\text { The MLR is not used, since we aggregated three risk } \\
\text { items to it, in the construct intrinsic risk (financial, } \\
\text { technological and market), but in the BLR it is used, since } \\
\text { universities and Tls in comparison to the other partners, } \\
\text { show higher technological risk and lower competitive } \\
\text { risk, supporting the hypothesis } \mathrm{H} 3 \mathrm{~d} \text { and } \mathrm{H} 3 \mathrm{e} \text { later on. }\end{array}$ & $\mathrm{H} 3 \mathrm{~b}$ is supported \\
\hline $\begin{array}{l}\text { H3.c. The risk is more positively related } \\
\text { marketing alliances with customers, com- } \\
\text { pared to other types of partners }\end{array}$ & $\begin{array}{l}\text { Again, the MLR is not used where the risk items were } \\
\text { added. In BLR alliances with clients versus other part- } \\
\text { ners, although there is a positive relationship, it has no } \\
\text { statistical significance ( } p \text { value of } 0.356 \text { ), leading to its } \\
\text { rejection. Also in the nonparametric Mann-Whitney, HO } \\
\text { cannot be rejected, leading to a lack of support for the } \\
\text { hypothesis. }\end{array}$ & $\mathrm{H} 3 \mathrm{c}$ is not supported \\
\hline $\begin{array}{l}\text { H3d. The lower competitive risk is associ- } \\
\text { ated with alliances with universities / Tls, } \\
\text { when compared to the others. }\end{array}$ & $\begin{array}{l}\text { In MLR, the competitive risk in alliances with universities } \\
\text { and Tls is lower than in alliances with customers, but } \\
\text { higher than in alliances with consulting firms, not offering } \\
\text { full support. However, when analyzing the BLR, we found } \\
\text { no support. Finally, the nonparametric Mann-Whitney } \\
\text { test confirmed the support of the hypothesis, in which } \\
\text { by showing a significance level of } 0.001 \text {, brings the } \\
\text { average ranking of the biggest score for other partners } \\
\text { to } 60.2 \% \text {. }\end{array}$ & $\mathrm{H} 3 \mathrm{~d}$ is supported \\
\hline
\end{tabular}

ISSN: 07 I8-2724. (http://www.jotmi.org) 


\begin{tabular}{|c|c|c|}
\hline $\begin{array}{l}\text { H3e. The competitive risk is more closely } \\
\text { related to alliances with customers (and } \\
\text { competitors), compared to the other } \\
\text { partners. }\end{array}$ & $\begin{array}{l}\text { This hypothesis needed to be reworded by deleting the } \\
\text { alliance with competitors, and keeping the comparison } \\
\text { of alliances with clients versus other partners. In MLR, } \\
\text { the competitive risk in alliances with customers is higher } \\
\text { than compared to the others, and the variable has signif- } \\
\text { icant coefficient, supporting the hypothesis. In BLR, with } \\
\text { P value of } 0.00 \text { I and Exp (B) of } 0.304 \text {, we notice that } \\
\text { there is statistical significance regarding the hypothesis. } \\
\text { In the Mann-Whitney test, the mean difference of the } \\
\text { highest ranking at } 63 \% \text { for alliances with customers has } \\
\text { significance of } 0.00 \text { I ( } \mathrm{p} \text { value }=0.000) \text {, supporting the } \\
\text { hypothesis. }\end{array}$ & $\mathrm{H} 3 \mathrm{e}$ is supported \\
\hline $\begin{array}{l}\text { H4a. The complementary technology (TC) } \\
\text { is more positively related to alliances with } \\
\text { universities and Tls or customers, com- } \\
\text { pared to the other partners. }\end{array}$ & $\begin{array}{l}\text { In MLR, in terms of TC, alliances with customers to } \\
\text { overcome the ones with the suppliers, which surpass } \\
\text { the ones with Universities and Tls which, in turn surpass } \\
\text { those with the consultancies, making it impossible to } \\
\text { support the hypothesis, added to the fact that none } \\
\text { of the relationships presented statistical significance. } \\
\text { Then, conducting the BLR, we obtained p value of } 0.052 \\
\text { for the coefficient of MC, significant at } 0.1 \text { and exp (B) } \\
\text { from } 0.552 \text { toward the case, corroborating it. In the } \\
\text { Mann-Whitney test the hypothesis also receives support, } \\
\text { with a significance of } 0.1 \text { ( }(p \text { value } 0.079 \text { ). }\end{array}$ & $\mathrm{H} 4 \mathrm{a}$ is supported \\
\hline $\begin{array}{l}\text { H4.b. The Market Compementarity (MC) } \\
\text { is more positively related to alliances with } \\
\text { customers and universities / Tls, when } \\
\text { compared to the other partners. }\end{array}$ & $\begin{array}{l}\text { In MLR, alliances with both customers and clients } \\
\text { show less market complementarity than alliances with } \\
\text { universities and IT's, with statistical significance, with } \\
\text { market complementarity being higher with customers } \\
\text { than with suppliers. However, as far as consultancies are } \\
\text { concerned, they show a higher MC than the universities } \\
\text { and Tls, although not statistically significant, not giving full } \\
\text { support to the hypothesis. Thus, we conducted the BLR, } \\
\text { in which the MC has a p value of } 0.064 \text {, significant at } 0.1 \\
\text { and exp (B) of } 0.588 \text { in the direction of the hypothesis, } \\
\text { corroborating it. In the Mann-Whitney test the hypothe- } \\
\text { sis also receives support, with a significance of } 0.01 \text {. }\end{array}$ & $\mathrm{H} 4 \mathrm{~b}$ is supported \\
\hline $\begin{array}{l}\text { H4c. The full complementarity }(\mathrm{C}) \text { is more } \\
\text { positively related to alliances with univer- } \\
\text { sities / Tls and customers, compared to } \\
\text { other types of partners. }\end{array}$ & $\begin{array}{l}\text { In BLR, the hypothesis is supported, with a significance } \\
\text { of } 0.05 \text { ( } p \text { value } 0.036) \text {, and in the hypothesized direction } \\
\text { (Exp (B) of } 0.604) \text {, indicating a greater likelihood of alli- } \\
\text { ance with universities / Tls and customers as compared } \\
\text { to others, with increasing total complementarity. We } \\
\text { also identified a support by the Mann-Whitney test, with } \\
\text { significance of } 0.05 \text {. ( } p \text { value de } 0,012 \text { ). }\end{array}$ & $\mathrm{H} 4 \mathrm{c}$ is supported \\
\hline $\begin{array}{l}\text { H5:The partner experience in alliances } \\
\text { becomes more crucial in alliances with uni- } \\
\text { versities / Tls than companies (competitors, } \\
\text { suppliers, customers and others). }\end{array}$ & $\begin{array}{l}\text { The MLR with aggregated constructs only discriminates } \\
\text { the U/TIs from theconsultancies. We proceed, then to } \\
\text { BLR, in which both the experience of partner alliances } \\
\text { and experience with the partner alliances are significant } \\
\text { in the formation of the logistic model, with a significance } \\
\text { of } 0.01 \text { and } 0.05 \text { respectively, but in different ways, i.e., } \\
\text { the experience of partner in alliances is less decisive in } \\
\text { alliances with companies, compared to universities and } \\
\text { IT's (Exp (B) of } 0.156 \text { ), confirming H4.I, whereas experi- } \\
\text { ence in alliances with a partner is more decisive (Exp (B) } \\
\text { of } 2.185 \text { ) in alliances with companies, compared to U/ } \\
\text { Tls. The Mann-Whitney test also confirms H5, indicating } \\
\text { a significance level of } 0.00 \text { I ( } P \text { value }=0.000 \text { ), an average } \\
\text { ranking of positions } 53.7 \% \text { higher for the partner's expe- } \\
\text { rience in alliances with universities and Tls, compared to } \\
\text { companies. }\end{array}$ & H5 is supported \\
\hline
\end{tabular}

ISSN: 07 I8-2724. (http://www.jotmi.org) 


\begin{tabular}{|c|c|c|}
\hline $\begin{array}{l}\text { H6. Confidence in partner becomes more } \\
\text { significant in alliances with companies } \\
\text { (competitors, suppliers, customers and } \\
\text { others) than with universities / Tls. }\end{array}$ & $\begin{array}{l}\text { Both in the MLR and the BLR, the trust construct is } \\
\text { not significant. In the nonparametric Mann-Whitney } \\
\text { test, there is no support, which makes the hypothesis } \\
\text { be rejected. It can be seen by descriptive statistics, that } \\
\text { trust in the partner is a determining factor in all alliances } \\
\text { relationships, regardless of the partner concerned, not } \\
\text { being possible to distinguish the groups. }\end{array}$ & $\mathrm{H} 6$ is not supported \\
\hline $\begin{array}{l}\text { H6a: Confidence in partner regarding } \\
\text { meeting deadlines and flexibility for adjust- } \\
\text { ments becomes more significant in alliances } \\
\text { with customers, suppliers and others than } \\
\text { in alliances with universities / Tls. }\end{array}$ & $\begin{array}{l}\text { Comparing the two groups in BLR, the hypothesis is } \\
\text { supported, with a significance level of } 0.1 \text { and Exp (b) of } \\
\text { I.926, i.e., one-point increase in this item makes the like- } \\
\text { lihood of the alliance being conducted with companies } \\
\text { and not with Universities and Tls, multiplied by a factor } \\
\text { almost two-fold. The nonparametric Mann-Whitney test, } \\
\text { while indicating a difference of } 6.15 \% \text { on the average } \\
\text { ranking positions in the hypothesized direction, has no } \\
\text { significance for the differentiation between the groups } \\
\text { with which the hypothesis is only partially accepted. }\end{array}$ & $\mathrm{H} 6 \mathrm{a}$ is partially supported \\
\hline $\begin{array}{l}\text { H6b. Confidence in partner regarding the } \\
\text { supply of competences is positively related } \\
\text { to perceived technological familiarity of the } \\
\text { partner. }\end{array}$ & $\begin{array}{l}\text { According to the correlation analysis, there is a correla- } \\
\text { tion of } 0.377 \text { at a significance level of } 0.01 \text {, supporting } \\
\text { the hypothesis. }\end{array}$ & $\mathrm{H} 6 \mathrm{~b}$ is supported \\
\hline $\begin{array}{l}\text { H7:The convergence of expectations } \\
\text { between the partners becomes more signif- } \\
\text { icant in alliances with companies (competi- } \\
\text { tors, suppliers, customers and others) than } \\
\text { with universities / Tls. }\end{array}$ & $\begin{array}{l}\text { Although the means were compared and values of Exp } \\
\text { (B) pointed to that direction, the MLR and the BLR show } \\
\text { no statistical significance. In the Mann-Whitney test, al- } \\
\text { though there is an average of } 12.7 \% \text { over the direction of } \\
\text { the companies, the null hypothesis could not be rejected } \\
\text { due to the p-value of } 0.355 \text {, not allowing the support of } \\
\text { the hypothesis. }\end{array}$ & $\mathrm{H7}$ is not supported \\
\hline $\begin{array}{l}\text { H8. The similarity of organizational culture } \\
\text { between the partners becomes more signif- } \\
\text { icant in alliances with companies (competi- } \\
\text { tors, suppliers, customers and others) than } \\
\text { with universities / Tls. }\end{array}$ & $\begin{array}{l}\text { In MLR this variable only discriminates universities / Tls } \\
\text { from consultancies, which show much higher intensity } \\
\text { of the variable. In the BLR between the two groups, the } \\
\text { variable discriminates, with a significance level of } 0.1 \text {. } \\
\text { The Mann-Whitney test indicates the difference in mean } \\
\text { ranking of positions of } 21.62 \% \text { for firms in comparison } \\
\text { to universities and Tls, with a significance level of } 0.1 \text {. }\end{array}$ & $\mathrm{H} 8$ is supported \\
\hline $\begin{array}{l}\text { H9a:The larger the size, the greater the } \\
\text { propensity to make alliances with universi- } \\
\text { ties / Tls. }\end{array}$ & $\begin{array}{l}\text { The MLR does not include the size of the model as a sig- } \\
\text { nificant variable. In cross-analyzes of descriptive statistics, } \\
\text { we see the behavior in the form of an inverted } U \text { curve, } \\
\text { i.e., there is an increasing linear association between two } \\
\text { variables, which means that the proportion of alliances } \\
\text { with universities and Tls decreases when going from } \\
\text { small to medium size, and increases again when going } \\
\text { from medium to large size. The correspondence analysis } \\
\text { confirms this result, and associates this type of partner } \\
\text { more to large and small companies than to the medi- } \\
\text { um-sized ones. }\end{array}$ & $\mathrm{H9a}$ is not supported \\
\hline $\begin{array}{l}\text { H9b:The larger the size, the greater the } \\
\text { propensity to make alliances with interna- } \\
\text { tional partners. }\end{array}$ & $\begin{array}{l}\text { Cross-analyzes of descriptive statistics show the behav- } \\
\text { ior in the form of an inverted U-shaped curve, i.e., from } \\
\text { small to medium-sized companies there is an increase in } \\
\text { international alliances, a rate that then decreases, when } \\
\text { going from medium to large-sized companies. The cor- } \\
\text { respondence analysis showed no statistically significant } \\
\text { association, making the hypothesis be rejected. }\end{array}$ & $\mathrm{H} 9 \mathrm{~b}$ is not supported \\
\hline
\end{tabular}




\begin{tabular}{|c|c|c|}
\hline $\begin{array}{l}\text { HIOa: International alliances are more re- } \\
\text { lated to projects of radical innovations than } \\
\text { the national alliances. }\end{array}$ & $\begin{array}{l}\text { Contrary to expectations, as discussed in the cross } \\
\text { - analysis and in the correlation analysis, the projects } \\
\text { that best use of international partners are incremental, } \\
\text { followed by platform-type projects,, radical ones, and } \\
\text { finally basic science projects. As we have seen, most sup- } \\
\text { pliers are international, where incremental projects are } \\
\text { developed, then assuming the logic that most of them } \\
\text { are situated on national territory. The case-company in } \\
\text { the phase of the qualitative research, the results suggest- } \\
\text { ed the creation of the hypothesis, perhaps because of it } \\
\text { having intensive R\&D and higher degree of international- } \\
\text { ization than the average of the chemical sector. }\end{array}$ & $\mathrm{HIOa}$ is not supported \\
\hline $\begin{array}{l}\text { HIOb: International alliances are most often } \\
\text { associated with alliances with customers } \\
\text { and suppliers than with universities/Tls. }\end{array}$ & $\begin{array}{l}\text { In the MLR and BLR, we identified the support for the } \\
\text { hypothesis. The correspondence analysis, with signifi- } \\
\text { cance level of } 0.05 \text {, also confirms, since the ranking for } \\
\text { international partners has a sequence of suppliers, then } \\
\text { consultants, followed by customers and finally the univer- } \\
\text { sities and TIs. Finally, the chi-square test, with significance } \\
\text { level of } 0.01 \text { ( } p \text { value of } 0.006 \text { ), confirms the difference in } \\
\text { the groups, with } 31.1 \% \text { of alliances with customers and } \\
\text { suppliers being carried out with international partners, } \\
\text { against only } 3.7 \% \text { for Universities and Tls by descriptive } \\
\text { statistics. }\end{array}$ & $\mathrm{HIOb}$ is supported \\
\hline $\begin{array}{l}\text { HIOc:Alliances with international partners } \\
\text { encompass greater market risk than allianc- } \\
\text { es with national partners. }\end{array}$ & $\begin{array}{l}\text { By the descriptive statistics, there is a difference of } 27.9 \% \\
\text { between these groups. In the Mann-Whitney test, the } \\
\text { largest difference of } 36.7 \% \text { on the average ranking of } \\
\text { the risk of post marketing alliances with international } \\
\text { partners is supported with a significance of } 0.05 \text { ( } p \text { value } \\
\text { of } 0.019 \text { ). }\end{array}$ & $\mathrm{HIOc}$ is supported \\
\hline $\begin{array}{l}\text { HIOd: International Alliances demands } \\
\text { partners with greater technological and } \\
\text { market familiarity than the national allianc- } \\
\text { es. }\end{array}$ & $\begin{array}{l}\text { The hypothesis is supported by the Mann-Whitney test } \\
\text { for both the technological familiarity of the partner, with } \\
\text { significance of } 0.1 \text { ( } p \text { value } 0.075 \text { ) and for the market } \\
\text { familiarity of the partner, with significance of } 0.05 \text { ( } p \\
\text { value of } 0.027 \text { ). }\end{array}$ & HIOd is supported \\
\hline $\begin{array}{l}\text { HI Ia: Project of alliances in basic science } \\
\text { and radical ones are most often associated } \\
\text { with alliances with universities/Tls, when } \\
\text { compared to the other partners. }\end{array}$ & $\begin{array}{l}\text { By the descriptive statistics, alliances with universities or } \\
\text { IT's are predominant in the categories of radical projects } \\
\text { and of basic science ( } 48.1 \%) \text {, followed by platform } \\
\text { projects ( } 37 \%) \text { and a small amount of incremental ones } \\
\text { (I4.8\%), supporting the hypothesis. Also, the hypothe- } \\
\text { sis is supported by the correspondence analysis, other } \\
\text { multivariate technique. }\end{array}$ & $\mathrm{HIIa}$ is supported \\
\hline $\begin{array}{l}\text { HI Ib: Projects of alliances for innovation } \\
\text { of the incremental and platform types are } \\
\text { less often associated with the alliance with } \\
\text { universities/TIs, when compared to the } \\
\text { other partners. }\end{array}$ & $\begin{array}{l}\text { By the descriptive statistics, alliances with customers } \\
\text { mainly refer to the platform type projects }(63 \%) \text { and } \\
\text { incremental ones ( } 33.3 \%) \text {, with little participation of radi- } \\
\text { cal projects ( } 3.7 \% \text { ) and lack of basic research. Likewise, in } \\
\text { the alliances with suppliers, the sum of the two cate- } \\
\text { gories reaches } 83.4 \% \text { of all projects in this category of } \\
\text { partner, which supports the hypothesis. Correspondence } \\
\text { analysis confirms this association, allowing support of the } \\
\text { hypothesis. }\end{array}$ & $\mathrm{HIIb}$ is supported \\
\hline $\begin{array}{l}\text { HI Ic:The greater complexity of the } \\
\text { project increases the likelihood that the } \\
\text { alliance be conducted with universities / Tls } \\
\text { vs. other. }\end{array}$ & $\begin{array}{l}\text { The MLR ensures support of the hypothesis. Also, the } \\
\text { nonparametric Mann-Whitney test is significant to } \\
\text { differentiate the two groups, with the support of the } \\
\text { hypothesis, with a difference of } 43.8 \% \text {. }\end{array}$ & $\mathrm{HIIC}$ is supported \\
\hline
\end{tabular}

Table 2:Testing of the hypotheses

ISSN: 07 I8-2724. (http://www.jotmi.org)

Journal of Technology Management \& Innovation (C) Universidad Alberto Hurtado, Facultad de Economía y Negocios. 


\section{Acknowledgements}

This study was carried out with the support of Brazilian Government research funding agencies (CAPES and CNPq).

\section{References}

ARCHIBUGI, D., Coco, A. (2004). International partnerships for knowledge in business academia: a comparison between Europe and the USA. Technovation, 24 (7), pp. 517-528.

ARIÑO, A., Abramov, M., Skorobogatykh, I., Rykounina, I., Vilá, J. (1997). Partner selection and trust building in West European-Russian joint ventures: A Western perspective. International Studies of Management and Organization, 27 (I), pp. 19-37.

ARORA,A., Gambardella,A. (1990). Complementary and external linkages: the strategies of large firms in biotechnology. Journal of Industrial Economics, n. 38, June, pp. 36I-379.

BALACHANDRA, R., Friar, JH (1997). Factors for success in R\&D projects and new product innovation: a contextual framework? IEEE Transactions on Engineering Management, 44 (3), pp. 276-287.

BIDAULT, F., Despres, C., Butler, C. (1998). The drivers of cooperation between buyers and suppliers for product innovation. Research Policy, 24, pp. 97-I I4.

BRUNO, M.A.C.,Vasconcellos, E.P.G. (2003).Applying a management framework to three high-sharing technological alliances. Revista Finanza Marketing e Produzione. Itália: 2 (XXI), pp. 107 - 126.

CASSIMAN, B.,Veugelers, R. (1998). R\&D cooperation and spillovers: some empirical evidence. Universitat Pompeu Fabra, working paper, n. 328.

CHESBROUGH, H. (2003). Open Innovation: The New Imperative for Creating and Profiting from Technology. Harvard Business School, Boston, MA.

CLARK, K.B.,Wheelright, S.C. (1993). Managing new product and process development: text and cases. New York: Maxwell Macmillan International, p.233-289.

DACIN, M.T., Hitt, MA, Levitas, E. (1997). Selecting Partners for Successful International Alliances: Examination of U.S. and Korean Firms. Journal of World Business, vol. 32, n. I, p. 3-16, 1997.

DEVLIN, G., Bleackley, M. ( 1988). Strategic alliances: - guidelines for success. Long Range Planning, 2 I (5), p. 18-23.
EINSENHARDT, K.M., Schoonhoven, C.B. (1996). Resourced-based view of strategic alliance formation: strategic and social effects in entrepreneurial firms, Organization Science, 7(2), p. I36-I50.

ELMUTI, D.Y., Kathawala, Y. (200I). An overview of strategic alliances. Management Decision, 39(3), p.205-2I7.

FRITSCH, M.; Lukas, R. (200I). Who co-operates on R\&D? Research Policy, 30, pp.297-3I2.

GARCEZ, M. P, Sbragia, R., Kruglianskas, I. (20I0). The Selection of Partners in Non-equity Bilateral Alliances - Some Qualitative Evidences from the Brazilian Petrochemical Leader. In: Proceedings of the PIMCET'IO Conference, Phuket, Thailand.

GARCEZ, M. P., Sbragia, R. (20I I). On the Selection of Partners in Technological Alliances in the Brazilian Chemical Sector. In: Proceedings of the IAMOT 20I I Conference, Miami, USA.

GARCIA, C.Q., Velasco, C.B. (2004). Cooperation, competition and innovative capability: a panel data of European dedicated biotechnology firms. Technovation, 24(I2), p. 927-938.

GERINGER, J.M. (1991). Strategic determinants of partner selection criteria in international joint ventures. Journal of International Business Studies, first quarter, 22(I), p. 4I-62.

GERINGER, J.M., Frayne, C.A. (1993). The Joint Venture Partner Selection Process. In: LORANGE, P., Chakravarthy, B., Roos, J. et al. (Eds.) Implementing Strategic Processes: Change, Learning and Co-operation. Blackwell, p. 253-272.

GRANT, R., Bade-Fuller, C.A. (2004). A knowledge accessing theory of strategic alliances. Journal of Management Studies, $4 I(I)$, p.6I-84.

JONASH, R.S., Sommerlatte, T. (1999). The Innovation Premium: How Next Generation Companies Are Achieving Peak Performance and Profitability. Perseus Books Group.

KOTABE, M., Swan, K.S. (1995). The role of strategic alliances in high-technology new product development. Strategic Management Journal, 16, p. 62I-636.

KOZA, M.P., Lewin, A.Y. (2000). Managing partnerships and strategic alliances: raising the odds of success. European Management Journal, I6(2), p. I46-I5I.

LAVIE, D. (2006). The competitive advantage of interconnected firms: an extension of the resource-based view.Academy of Management Review, 3I(3), p. 638-658. 
LIKER, J.K., Kamth, R.R., Wasti, S.N., Nagamachi, M. (1996). Supplier involvement in automotive component design: are there really large US Japan differences? Research Policy, n. 25 , p. 59-89.

LOWE, J., Taylor, P. (1998). R\&D and technology purchase trough licence agreements: complementary strategies and complementary assets. R\&D Management , 28(4), p. 263-278.

MEDCOF, J.W. (1997). Why too many alliances end in divorce. Long Range Planning, 30(5), p. 7 I 8-732.

MIOTTI, L., Sachwald, F. (2003). Co-operative R\&D: why and with whom? An integrated framework of analysis. Research Policy, 32, p. | |48|-| 499.

NALEBUFF, B.J., Brandenburger, A. M. (1996). Co-opetição. Rocco, Rio de Janeiro.

PARK, N.K., Mezias, J.M., Song, J. (2004). A resource-based view of strategic alliances and firm value in the electronic marketplace. Journal of Management, 30(I), p. 7-27.

PMBOK. Project Management Institute. Um guia do conjunto de conhecimentos em gerenciamento de projetos (PMBOK® Guide). EUA: PMI, 2004.

POWELL, W.W., Kogut, K.W., Smith-Doerr, L. (1996). Interorganizational collaboration and the locus of innovation: networks of learning in biotechnology. Administrative Science Quarterly, 4I.

ROBERTS, E. B., Berry, C.A. (1985). Entering new businesses - selecting strategies for success. MIT Sloan Management Review, Cambridge, MA, spring, p. 3-17.

ROMAN, M. (2009). Inter-organizational relationships in innovation processes: A microfoundations approach. Doctoral Dissertation, Helsinki University of Technology, Espoo, Finland.

SAKO, M. (1994). Supplier relationships and innovation. In: Dodgson, $M$ and Rothwell, R (Eds.), The Handbook of Industrial Innovation, Edward Elgar, Cheltenham, UK.

SAVIOZ, P., Sannemann, E. (1999). The concept of the integrated innovation process. In: Proc. of the PIMCET'99, eds Kocaoglu, DF and Anderson, TR, Portland-USA.

SORENSEN, H.B., Reve,T. (1998). Forming strategic alliances for asset development. Scandinavian Journal of Management, I4(3), p. I5I-165.
STARAPOLI, C. (1998). Cooperation in R\&D in the pharmaceutical industry - the network as an organizational innovation governing technological innovation. Technovation, I8(I), p. I3-23.

TETHER, B.S. (2002). Who co-operates for innovation, and why. An empirical analysis. Research Policy, 31.

VERSPAGEN, B., Duysters, G. (2004). The small worlds of strategic technology alliances. Technovation, vol. 24, n. 7, p. 563-57I. 